\title{
A survey of indications of MTP and concurrent contraceptive practices in a tertiary care institute
}

\author{
Mahima Jain* \\ Department of Obstetrics \& Gynecology, PDU Medical College, Rajkot, Gujarat, India
}

Received: 26 August 2014

Accepted: 10 September 2014

\author{
*Correspondence: \\ Dr. Mahima Jain, \\ E-mail: drmahimajain@yahoo.co.in
}

Copyright: $\odot$ the author(s), publisher and licensee Medip Academy. This is an open-access article distributed under the terms of the Creative Commons Attribution Non-Commercial License, which permits unrestricted non-commercial use, distribution, and reproduction in any medium, provided the original work is properly cited.

\begin{abstract}
Background: Despite liberalization of MTP services \& awareness of contraception maternal mortality due to induced abortion is high in India. This is a prospective analysis done to know the various reasons for seeking Induced abortion and the subsequent adoption of contraceptive methods concurrently. Lack of availability, misinformation \& apprehension about the various contraceptive options prevents their use and abortion is at times used as an alternative to contraception.

Methods: It was a cross-sectional study of 763 women availing facilities of MTP at PDU medical college, Rajkot, Gujarat. Socio-demographic profile, reasons for seeking MTP, concurrent contraceptive practice were studied.

Results: Amongst the socio-demographic profile, 55.6\% women are between 20-30 years. $64.5 \%$ women seeking MTP have less than 2 living children. Family completed is the reason for MTP in 55.9\%. The concurrent contraceptive adopted are $\mathrm{Cu}-\mathrm{T}$ and permanent sterilization by $23.3 \%$ and $55.9 \%$ women respectively.

Conclusions: Unmet need of contraception is high in India. Eligible couples especially from lower socio-economic class need to be educated for the various contraceptives available to prevent unwanted pregnancy. Counselling for post-abortal contraception is also the need of the hour.
\end{abstract}

Keywords: Indications, MTP, Contraceptive practices

\section{INTRODUCTION}

Although there are indications of steady increase in the number of abortions over the years, data on the attitude, behavior \& practices related to induced abortions are needed to improve the accessibility \& utilization of this services. ${ }^{3}$

Worldwide and in India, unsafe abortion is still recognized as a leading cause of maternal death, causing $13 \%$ of pregnancy-related mortality. ${ }^{4}$ With the enforcement of MTP Act in 1971, India became one of the first countries legalizing abortion. ${ }^{2}$

Many of the females are still not aware of the legal \& safe abortion facilities and many of them are forced to seek unsafe abortions for cultural reasons. In India about
6 million abortions take place every year, out of which 4 million are induced and 2 million spontaneous. ${ }^{4}$

Despite liberalization of MTP services and awareness of family planning methods maternal mortality due to induced abortion is high in India. ${ }^{1}$

This study is done to know the indications under which women seek induced abortion services at our institute.

\section{Objectives}

To study the patient profile in regards to age, socioeconomic status, parity etc.

To know the various concurrent contraceptive practices adopted by these women. 


\section{METHODS}

This was a cross-sectional study conducted prospectively on the women attending post-partum unit OPD of PDU medical college, Rajkot, to avail MTP services. The duration of study is one year from April 2013 to March 2014. During this period a total of 763 women underwent MTP data of which were studied and analysed.

The data is recorded on a pre-designed form and later analysed on various heads such as socio-demographic profile which included age, residence, socio-economic class, parity.

Information on the grounds under which the women want MTP services i.e. Indications is studied. The women are counseled regarding concurrent contraceptive methods with MTP services in the OPD. These are also recorded and analysed under the various methods women opted for during these services.

This is a simple survey hence does not pose any risk to the clients at the same time does not pass any cost to the institute. Institutional ethical committee has been informed but since it is a survey as such does not require permission for the same.

Data collected is the analysed statistically by number and percentage distribution.

\section{RESULTS}

As shown below (Table 1) $55.7 \%$ women seeking MTP are between 20-30 years which suggests the need to increase awareness in regards to various family planning measures available to them. Further their misconceptions in regards to the acceptance to these methods are also need of the hour. This is comparable with other studies which further stresses the need to improve counselling services by health workers to prevent unwanted pregnancies.

In our study $39.1 \%$ rural women and $60 \%$ urban women seeked MTP services, this might be due to location of our institute. But further this indicates to increase awareness of contraception among urban females as much as in the rural population.

$74.8 \%$ female seeking MTP services are from the lower socio-economic class, which clearly states the high unmet needs of contraception.

As shown in the below Table (Table 2) majority women seeking MTP have at least 2 living children. These are the couples which require counseling to prevent unwanted pregnancies as even though their family is completed but are reluctant or at times have misinformation of various contraceptives available for them. $^{5}$
Table 1: Demographic profile.

\begin{tabular}{|c|c|c|c|c|}
\hline & $\begin{array}{l}\text { No. in } \\
\text { our } \\
\text { study }\end{array}$ & $\begin{array}{l}\text { Percentage } \\
(\%)\end{array}$ & $\begin{array}{l}\text { Shipra } \\
\text { Gupta } \\
\text { et al. } \\
(\%)^{4}\end{array}$ & $\begin{array}{l}\text { Shankaraiah } \\
\text { RH et al. } \\
(\%)^{3}\end{array}$ \\
\hline \multicolumn{5}{|c|}{ Age (years) } \\
\hline $18-30$ & 425 & 55.7 & 68.42 & 49.5 \\
\hline $30-40$ & 314 & 41.2 & 23.03 & 39.8 \\
\hline $40-45$ & 24 & 3.2 & 4.6 & 8.8 \\
\hline \multicolumn{5}{|c|}{ Residence } \\
\hline Rural & 298 & 39.1 & 24.34 & \\
\hline Urban & 465 & 60.1 & 46.05 & \\
\hline \multicolumn{5}{|c|}{ SE class } \\
\hline Lower & 571 & 74.8 & 73.68 & 39.8 \\
\hline Middle & 160 & 20.9 & 21.05 & 32 \\
\hline Upper & 32 & 4.2 & 5.27 & 17.5 \\
\hline
\end{tabular}

Table 2: Distribution of women as per parity.

\begin{tabular}{|lll|}
\hline Parity & $\begin{array}{l}\text { No. in our } \\
\text { study }\end{array}$ & $\begin{array}{l}\text { Percentage } \\
(\%)\end{array}$ \\
\hline$\leq 2$ & 492 & 89.6 \\
\hline $3-4$ & 236 & 30.9 \\
\hline$>4$ & 35 & 4.5 \\
\hline
\end{tabular}

Majority studies compile the same data in regards to the parity of the women seeking MTP services (Table 3).

Table 3: Comparative studies for parity.

\begin{tabular}{|lll|}
\hline Parity & $\begin{array}{l}\text { Shipra Gupta } \\
\text { et al. (\%) }\end{array}$ & $\begin{array}{l}\text { Shankaraiah } \\
\text { RH et al (\%) }\end{array}$ \\
\hline$\leq 2$ & 47.37 & 47.5 \\
\hline$>3$ & 36.18 & 8.7 \\
\hline
\end{tabular}

The most common reason women seeked MTP services is family completed in $55.9 \%$, other reasons stated by the women are socio-economic reason, medical, contraceptive failure, previous baby too young and not wanting child at present (Table 4).

Table 4: Indications for MTP.

\begin{tabular}{|lllll|}
\hline Indications & $\begin{array}{l}\text { No. in } \\
\text { our } \\
\text { study }\end{array}$ & $\%$ & $\begin{array}{l}\text { Shipra } \\
\text { Gupta } \\
\text { et al. } \\
(\%)^{4}\end{array}$ & $\begin{array}{l}\text { Shankaraiah } \\
\text { RH et al. } \\
(\%)^{3}\end{array}$ \\
\hline $\begin{array}{l}\text { Family } \\
\text { completed }\end{array}$ & 427 & 55.9 & 63.16 & 39.8 \\
\hline Socioeconomic & 178 & 23.3 & 17.76 & 9.1 \\
\hline Medical & 10 & 13.1 & 4.61 & 11.6 \\
\hline $\begin{array}{l}\text { Contraceptive } \\
\text { failure }\end{array}$ & 48 & 6.3 & 9.21 & \\
\hline $\begin{array}{l}\text { Previous baby } \\
\text { too young }\end{array}$ & 79 & 10.4 & 20.4 & \\
\hline $\begin{array}{l}\text { Not wanting } \\
\text { child at present }\end{array}$ & 21 & 2.7 & 29.61 & \\
\hline
\end{tabular}


In our institute concurrent contraceptive adopted by the women are $\mathrm{Cu} \mathrm{T}$ in $23.3 \%$ and Lap $\mathrm{TL}$ by $55.9 \%$. Whereas $20.7 \%$ females did not go for any contraception. As such it is needed that more number of females need to be counseled to adopt one or other method for contraception at time of termination to avoid further unwanted pregnancies. Thereby frequent induced abortions and its related complications can be avoided. ${ }^{1,2}$

Table 5: Contraceptive methods used.

\begin{tabular}{|llcll|} 
Contraceptive & $\begin{array}{l}\text { No. in } \\
\text { our } \\
\text { study }\end{array}$ & $\%$ & $\begin{array}{l}\text { Shipra } \\
\text { Gupta } \\
\text { et al. } \\
(\%)^{4}\end{array}$ & $\begin{array}{l}\text { Shankaraiah } \\
\text { RH et al. } \\
(\%)^{3}\end{array}$ \\
\hline Cu T & 178 & 23.3 & 34 & 23 \\
\hline Lap TL & 427 & 55.9 & 64 & 40.3 \\
\hline None & 158 & 20.7 & 2 & 18 \\
\hline
\end{tabular}

\section{DISCUSSION}

In the present study $55.7 \%$ women are between $20-30$ years of age. As this is the peak reproductive age group where there is lack of motivation and decision making for contraceptive measures amongst the females. This is well supported by other studies.

In our study $60.9 \%$ women are from urban area as location of the institute within city premises which drains patients from various regions.

About $74.8 \%$ women belong to lower socio-economic class as various reasons such as the level of literacy and thereby ignorance to contraceptive methods available. This signifies the high unmet needs for contraception.

Majority of women $64.5 \%$ had $\leq 2$ parity who seeked MTP, as despite of completed family these females had unwanted pregnancies which again shows apprehension to using various contraceptives. ${ }^{5}$

The various reasons under which women seeked MTP family completed was found in $55.9 \%$.

Several studies indicate that most abortions are sought to limit family size or space the next pregnancy. Amongst the contraceptives accepted, $\mathrm{Cu} \mathrm{T}$ in $23.3 \%$ cases \& permanent sterilization like Lap TL in $55.9 \%$ cases which is comparable with other studies. ${ }^{1}$

\section{CONCLUSIONS}

Our study shows that women in the age group of 20-30 years, from lower socio-economic class are more vulnerable to unwanted pregnancies. The major reasons under which women seek MTP are completed family size, socio-economic conditions, previous young child and medical. Ignorance, lack of availability, misinformation and apprehension about various contraceptive methods at times poses women to have unwanted pregnancies. Hence MTP and family planning measures at times in reality go hand in hand. Nearly $80 \%$ women adopted a concurrent contraception after counseling, but still $20 \%$ cases need to be more encouraged to adopt these measures.

Funding: No funding sources

Conflict of interest: None declared

Ethical approval: The study was approved by the institutional ethics committee

\section{REFERENCES}

1. Dhillon BS, Chandiok N, Kambo I, Saxena NC. Induced abortion \& concurrent adoption of contraceptive in the rural areas of India (An ICMR task force study). Indian J Med Sci. 2004;58:478-84.

2. Johnston HB. Abortion practice in India: a review of literature. Abortion Assessment Project in India, CEHAT, 2002. Available at: http://www.commonhealth.in/safe_abortion/308.pdf.

3. Shankaraiah RH, Annadani RR, Vijayashankar V, Undi M. Medical Termination of pregnancy \& subsequent adoption of contraception. Int J Reprod Contracept Obstet Gynecol. 2013 Sep;2(3):367-71.

4. Shipra Gupta, Viral Dave, Kishor Sochaliya, Sudha Yadav. A study on socio demographic \& obstetric profile of MTP seekers of Guru Gobind Singh Hospital, Jamnagar. Healthline. 2012;3(1):50-4.

5. Chandik N, Kambo I, Dhillon BS, Saxena NC. Contraceptive knowledge practices \& utilization of services in the rural areas of India (An ICMR task force study). Indian J Med Sci. 2003;57:303-10.

DOI: $10.5455 / 2320-1770$. ijrcog20141238

Cite this article as: Jain M. A survey of indications of MTP and concurrent contraceptive practices in a tertiary care institute. Int J Reprod Contracept Obstet Gynecol 2014;3:1073-5. 